\title{
Effects of osmotic stress on crustacean larval growth and protein and lipid levels are related to life-histories: The genus Armases as a model
}

\author{
Gabriela Torres $^{\mathrm{a}, \mathrm{b}, *}$, Luis Giménez ${ }^{\mathrm{a}, \mathrm{c}}$, Klaus Anger ${ }^{\mathrm{a}}$ \\ ${ }^{a}$ Biologische Anstalt Helgoland, Foundation Alfred Wegener Institute for Polar and Marine Research, 27498 Helgoland, Germany \\ ${ }^{\mathrm{b}}$ AG Zoosystematik \& Morphologie, Carl von Ossietzky Universität Oldenburg, 26129 Oldenburg, Germany

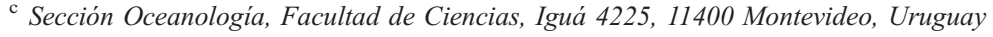 \\ Received 24 January 2007; received in revised form 30 May 2007; accepted 31 May 2007 \\ Available online 6 June 2007
}

\begin{abstract}
In the larval stages of three euryhaline species of the genus Armases, we tested if changes in biomass (dry mass, W; protein; lipid) under hyposmotic stress were related to their salinity tolerance, capabilities of osmoregulation, and migration patterns. As model species, we compared Armases miersii, which breeds in supratidal rock pools, the riverine crab Armases roberti (showing a larval export strategy), and Armases ricordi, whose larvae probably develop in coastal marine waters. At each stage, larvae were exposed to different salinities (selected according to previous information on larval survival; range: $5 \% 0-32 \%$ for $A$. miersii, $10 \% 0-32 \%$ for $A$. roberti, and $15 \% 0-32 \%$ for $A$. ricordi). Biomass was measured in early postmoult and intermoult. The larvae of the strongly osmoregulating species $A$. miersii, which develop in habitats with highly variable salinity conditions, showed the smallest variations in biomass. The effect on A. roberti varied during its ontogeny: the Zoea I and the Megalopa, which carry out downstream and upstream migrations, respectively, showed lower biomass variations than the intermediate zoeal instars, which develop in coastal waters. The larvae of $A$. ricordi showed generally the highest variations in biomass, reflecting poor adaptation to salinity variations. In addition, a common pattern was found for these estuarine species: the maximum of biomass shifted during ontogeny from $32 \%$ to $25 \%$, reflecting changes of the iso-osmotic point. The ontogeny of osmoregulation reflected ontogenetic migration patterns, which allow for avoiding detrimental effects of salinity variations.
\end{abstract}

(C) 2007 Elsevier Inc. All rights reserved.

Keywords: Armases miersii; Armases ricordi; Armases roberti; Osmotic stress; Larval development; Larval growth; Lipid content; Protein content

\section{Introduction}

Variations in salinity affect the volume of water and the concentrations of soluble compounds in aquatic organisms, and in consequence, alter the performance of their internal systems. The maintenance of a stable cellular composition is achieved through ion-regulation strategies (for review see Péqueux, 1995). In coastal and estuarine waters, changes in salinity play therefore a central role for the survival and growth of planktonic larvae and other invertebrates, as well as fish (Kinne, 1971). In particular, biomass and chemical composition are affected by

\footnotetext{
* Corresponding author. Biologische Anstalt Helgoland, Foundation Alfred Wegener Institute for Polar and Marine Research, 27498 Helgoland, Germany. Tel.: +49 4725819 3348; fax: +49 47258193369 .

E-mail address: Gabriela.Torres@awi.de (G. Torres).
}

reduced salinities (Anger, 2001, 2003; Anger et al., 2000; Torres et al., 2002).

Fully marine decapod crustaceans (e.g. Cancer pagurus, Hyas araneus) are generally osmoconformers, which are restricted to habitats with little variability in salinity (Péqueux, 1995). Many other crustaceans, however, can live in environments with variable salinity conditions. The benthic juvenile and adult stages of estuarine, semiterrestrial and terrestrial decapods, for instance, have evolved numerous physiological and behavioural adaptations to their physically variable environments (Greenaway, 1999). Nevertheless, their planktonic larvae are in most cases osmoconformers and remain therefore vulnerable to osmotic stress. Most of those species evolved larval "export strategies" (Strathmann, 1982), i.e. their physiologically sensitive larvae are transported to waters with more stable conditions (e.g. Armases roberti: Diesel and Schuh, 1998; Torres et al., 2006; Chasmagnathus granulata: Anger et al., 
1994; Charmantier et al., 2002; Eriocheir sinensis: Herborg et al., 2003; Cieluch et al., 2007). A lesser number of species develops through euryhaline, osmoregulating larval instars, which can successfully cope with strong salinity variations (e.g. Armases miersii, Charmantier et al., 1998). In these cases of advanced adaptation to non-marine conditions, the larval stages can be retained within the parental habitats ("retention strategy"; Strathmann, 1982).

Torres et al. (2002) found that larval biomass (dry mass, protein, lipid content) of weakly osmoregulating Zoea-I larvae was less affected by low salinity than the biomass of stenohaline osmoconforming zoeae. These results suggested that effects of low salinity on larval biomass (a) might vary with life-history strategies and ontogenetic patterns of osmoregulation, and (b) should be less detrimental in species with strongly osmoregulating larvae. In the present study, we tested these predictions. We expected that a reduced salinity should produce weaker effects on larval biomass in species, which live in highly variable habitats and show a retention strategy, as compared to those exporting their larvae to coastal marine waters. In addition, we tested if larval instars that are involved, in their natural environment, in ontogenetic migrations between rivers and coastal waters are less susceptible to salinity reductions than the intermediate instars of the same species, which normally develop in coastal waters with higher and more stable salinities.

To test these hypotheses, we compared three species of $\mathrm{Ar}$ mases, which live in different environments and show different reproductive strategies: (1) The larval development of a strong osmoregulator, A. miersii, occurs in isolated supratidal rock pools, where a wide range of salinity variation from freshwater to concentrated seawater occurs (Anger, 1995; Schuh and Diesel, 1995). (2) The larvae of Armases ricordi are directly released into coastal marine waters (Diesel and Schuh, 1998). (3) A. roberti shows a larval export strategy consisting of a rapid passive transport of the Zoea I from the riverine parental habitat



Fig. 1. Experimental design to study effects of salinity on dry mass and biochemical composition during larval development of A: Armases miersii, B: A. ricordi, C: A. roberti. Postmoult and intermoult samples (see arrows) were taken immediately after hatching or moulting $(0 \%)$ and at $50 \%$ of the moult cycle, respectively. 


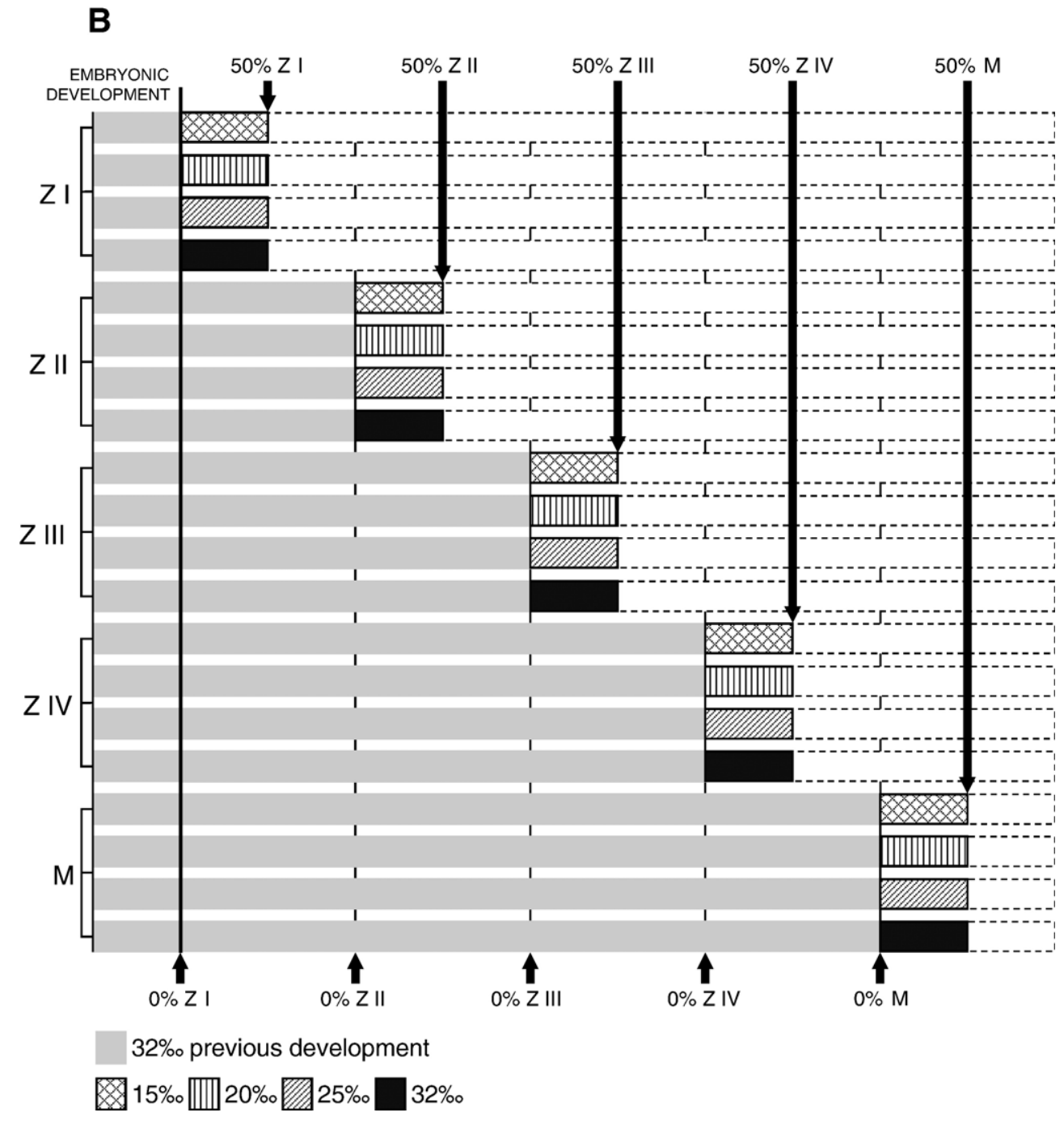

Fig. 1 (continued).

to coastal waters and a later re-immigration of the Megalopa to freshwater habitats (Diesel and Schuh, 1998; Torres et al., 2006; Anger et al., 2006).

\section{Materials and methods}

\subsection{Model species}

\subsubsection{A. miersii (Rathbun)}

The distribution range of this semiterrestrial crab includes the Caribbean islands, Florida and the Bahamas (Abele, 1992). On the northern shore of Jamaica, the juvenile and adult crabs live hidden in crevices between mangrove roots or on subtidal rocks as well as in coastal limestone caves with brackish or fresh water, breeding in coastal mangrove swamps and in land-locked supratidal rock pools (Anger, 1995; Schuh and Diesel, 1995). Its larval development consists of three zoeal stages and a Megalopa (Cuesta et al., 1999). The physicochemical conditions in the breeding pools are highly variable, particularly regarding salinity. Larval development in such harsh environment is possible, because all larval stages are able to osmoregulate (Charmantier et al., 1998). The zoeae hyperosmoregulate at low salinities and osmoconform at salinities higher than 25\%. The Megalopa and the subsequent juvenile stages reveal a weakly developed but gradually increasing capability of hyper-hypo-osmoregulation, i.e. hyper-regulation at low salinities and a slight hypo-regulation at salinities higher than $25 \%$. The adults show a strong capacity to hyper-hypoosmoregulate in conditions ranging from freshwater to concentrated media (Charmantier et al., 1998; Schubart and Diesel, 1998).

\subsubsection{A. ricordi (H Milne Edwards)}

This highly terrestrial species ranges between Bermuda, Surinam and the Gulf of Mexico (Abele, 1992). It occupies typical dry coastal mangrove habitats as well as rocks and debris in the supralittoral fringe up to ca. 200 meters inland (Hartnoll, 1965; Chace and Hobbs, 1969; Abele, 1992). The ovigerous females migrate to the sea to release the larvae into coastal marine waters (Diesel and Schuh, 1998). All larval 


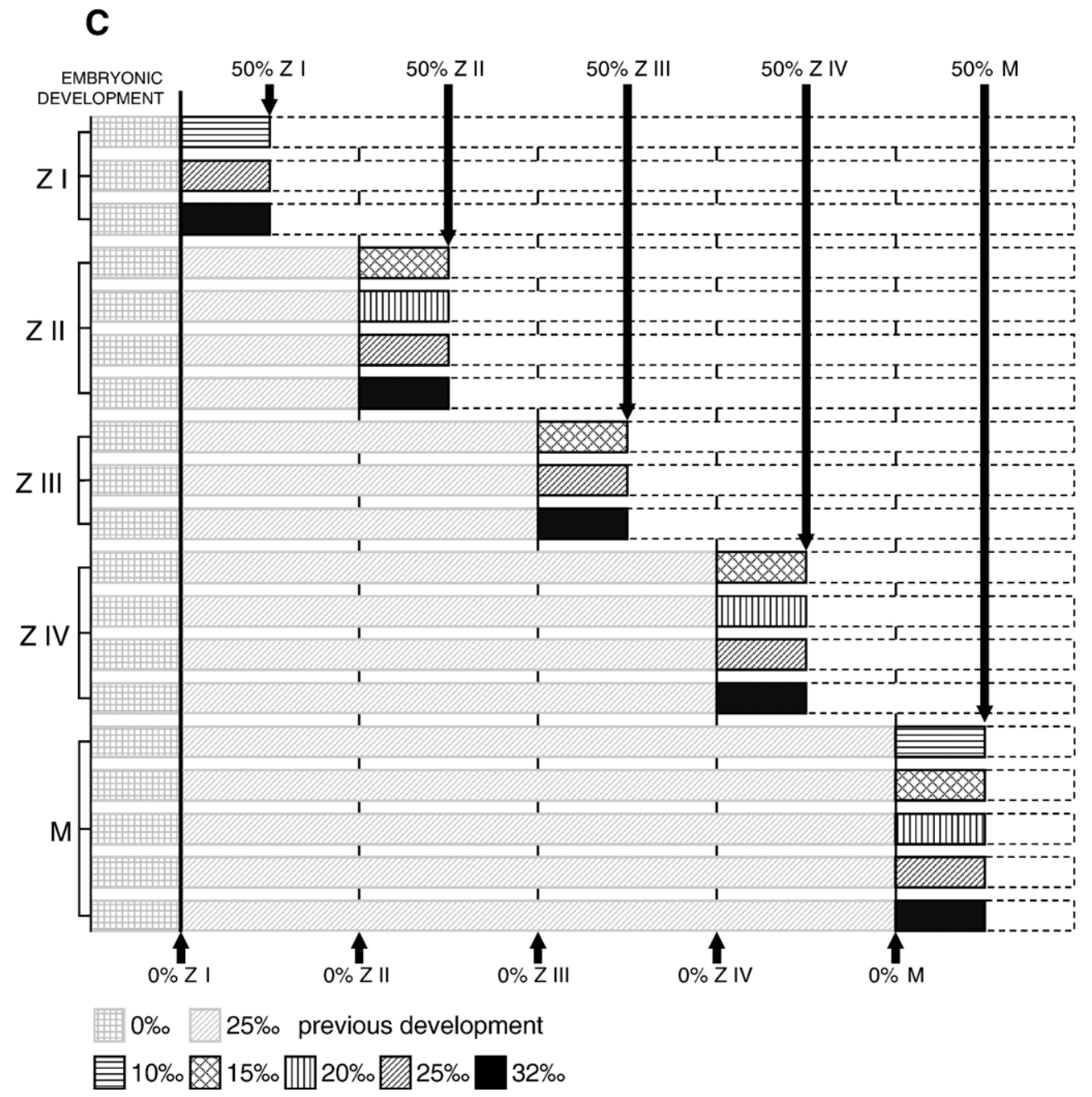

Fig. 1 (continued)

stages (four zoeae and a Megalopa; Guerao et al., in press) develop in the coastal planktonic environment (Díaz and Ewald, 1968; Alvarez and Ewald, 1990). They show a relatively narrow range of salinity tolerance, with high survival between $15 \%$ and $45 \%$ (G Torres, preliminary experiments). The four zoeal stages can slightly hyperosmoregulate between $15 \%$ and $32 \%$ and osmoconform at higher salinities (Charmantier et al., unpublished data). The Megalopa, surviving in a wider salinity range $(5 \% 0-45 \%)$, shows a fairly strong hyper-osmoregulatory capacity between $5 \%$ and $25 \%$ and an incipient hypo-regulation at higher salt concentrations. The adult crabs are strong hyper-hypoosmoregulators (Schubart and Diesel, 1998).

\subsubsection{A. roberti (H Milne Edwards)}

This little known tropical species is found in the West Indies, but not on the American mainland (Abele, 1992). The adult crabs live on the banks of rivers and streams from the mouth to ca. $10 \mathrm{~km}$ upstream (Chace and Hobbs, 1969; Abele, 1992; Anger et al., 2006). According to Diesel and Schuh (1998), the first zoea is released directly into freshwater near the semiterrestrial habitats of the adult population. Hence, the freshly hatched larvae are carried downstream by the river currents, so that they soon reach estuarine or coastal waters. The exported larvae develop in osmotically more stable waters through four zoeal stages to the megalopa (Guerao et al., in press). The latter is presumed to migrate back into estuaries and, probably, further upstream into riverine habitats (Torres et al., 2006; Anger et al., 2006). In agreement with this tentative migration pattern, the Zoea I shows a wide range of salinity tolerance (0-50\%; Diesel and Schuh, 1998), hyper-osmoregulating between $5 \%$ and $32 \%$ and osmoconforming at

Table 1

Time of exposure to experimental salinities ( $c a .50 \%$ of each moulting cycle)

\begin{tabular}{llll}
\hline Stage & Armases miersii & Armases ricordi & Armases roberti \\
\hline Zoea I & $24 \mathrm{hs}$ & 2 days & 2 days \\
Zoea II & 2 days & 2 days & $36 \mathrm{~h}$ \\
Zoea III & 2 days & 2 days & 2 days \\
Zoea IV & - & $36 \mathrm{~h}$ & 3 days \\
Megalopa & 2 days & 5 days & 4 days \\
\hline
\end{tabular}


Table 2

Armases miersii. Two-way ANOVA to evaluate the effect of salinity and larval instar on dry mass, protein and lipid content (log-transformed data)

\begin{tabular}{|c|c|c|c|c|c|c|c|c|c|}
\hline \multirow[b]{2}{*}{ Factor } & \multicolumn{3}{|c|}{ Dry mass } & \multicolumn{3}{|c|}{ Protein } & \multicolumn{3}{|c|}{ Lipids } \\
\hline & $d f$ & MS & $F$ & $d f$ & MS & $F$ & $d f$ & MS & $F$ \\
\hline Instar $(I)$ & 3 & 821 & $3747 * * *$ & 3 & 1394 & $7470 * * *$ & 3 & 380 & $355^{* * *}$ \\
\hline$I \times S$ & 12 & 1.8 & $8.0^{* * *}$ & 12 & 0.4 & $1.9^{* * *}$ & 12 & 1.2 & $1.1^{\mathrm{ns}}$ \\
\hline Error & 85 & 0.2 & & 81 & 0.2 & & 85 & 1.1 & \\
\hline
\end{tabular}

Symbols: $d f$ : degrees of freedom, MS: means squares. Mean squares are $\left(1 \times 10^{-2}\right)$. Significant levels are indicated as follows: ns: non-significant; $*:<0.05, * *:<0.01$, $* * *:<0.001$.

higher salinities (Charmantier et al., unpublished data). The following larval stages have a narrower range of salinity tolerance (15-45\%; Diesel and Schuh, 1998), coinciding with a lower hyper-osmoregulatory capacity. The tolerance of salinity variation increases again after metamorphosis to the Megalopa, which is able to strongly hyper-osmoregulate between $0 \%$ and $25 \%$ and slightly hypo-osmoregulate at higher salinities. The iso-osmotic point shifts during the course of larval development from $32 \%$ to $25 \%$ o (Charmantier et al., unpublished data). As in the previous species of Armases, the adult crabs are strong hyper-hypo-osmoregulators (Schubart and Diesel, 1998).

\subsection{Handling of ovigerous females and larval rearing}

Larvae of $A$. miersii, $A$. roberti, and $A$. ricordi were obtained from ovigerous females, which had been collected near the Discovery Bay Marine Laboratory (DBML), Jamaica. After transport to the Helgoland Marine Biological Station (BAH, Helgoland, Germany), the crabs were maintained in an aerated circulating water system, under controlled conditions of temperature $\left(24{ }^{\circ} \mathrm{C}\right)$, salinity (25\% for A. miersii; $32 \%$ for A. ricordi; $0.2 \%$ for $A$. roberti), a light/dark cycle of $12 \mathrm{~L}: 12 \mathrm{D}$, and feeding ad libitum with frozen isopods, Idotea sp. (for further details of habitat characteristics, collection, and long-
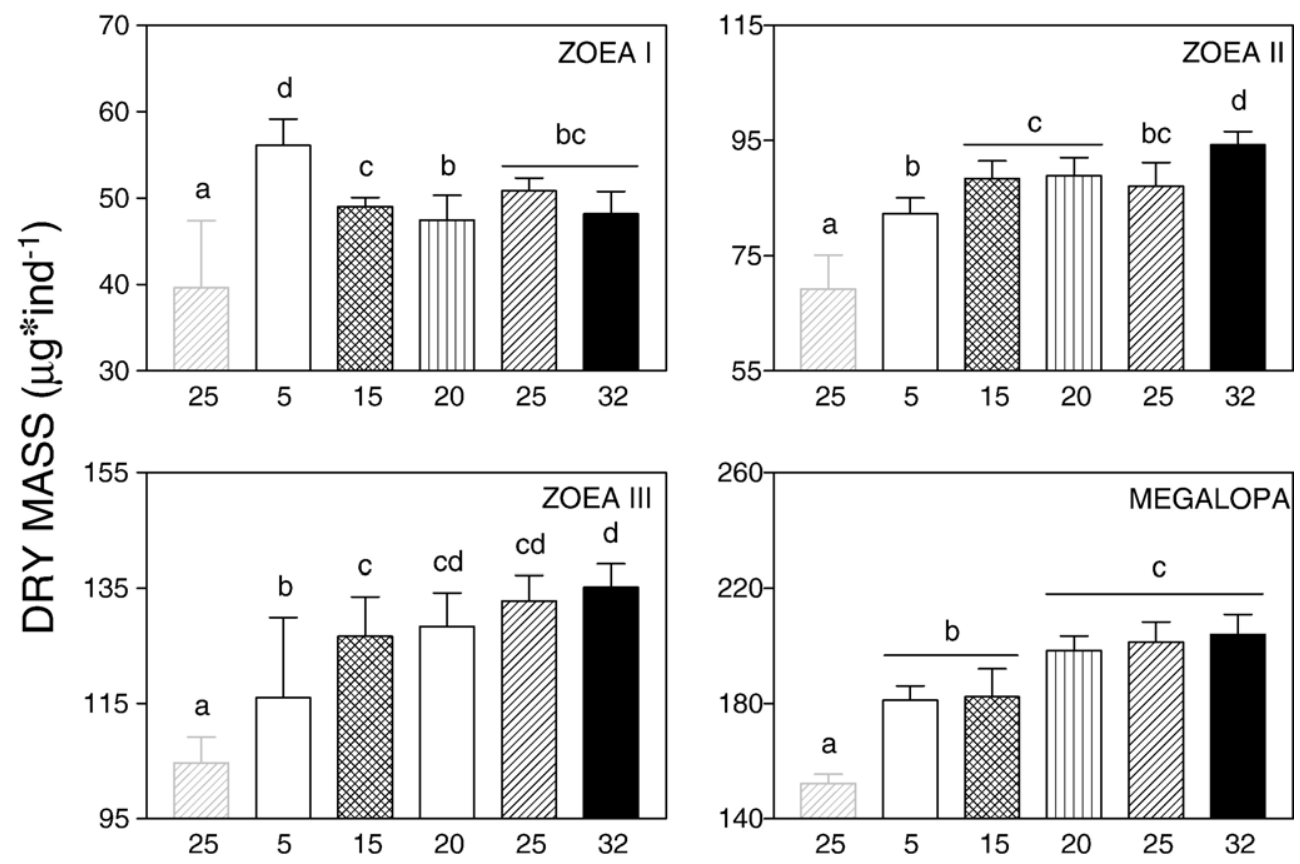

SALINITY (\%o)

INITIAL SALINITY: 25\%。

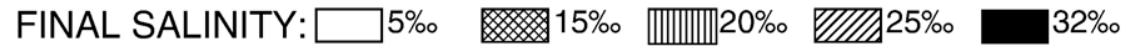

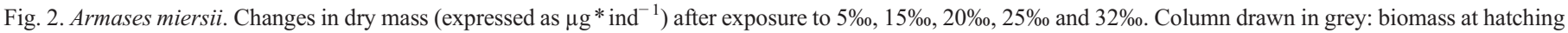

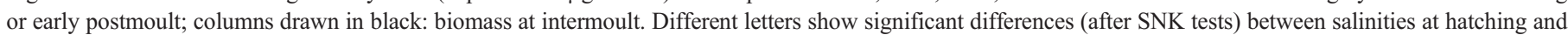
intermoult. 

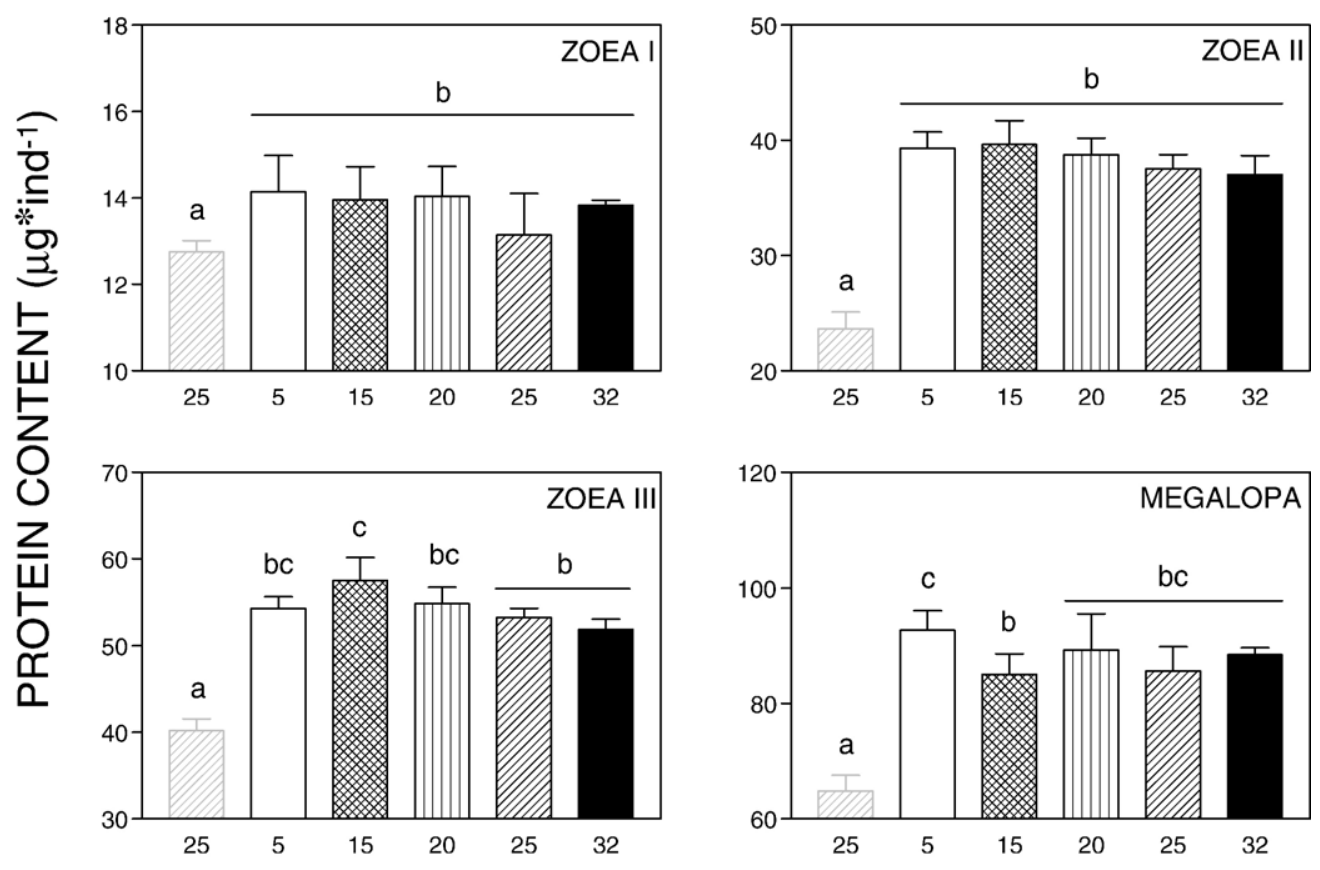

SALINITY (\%o)

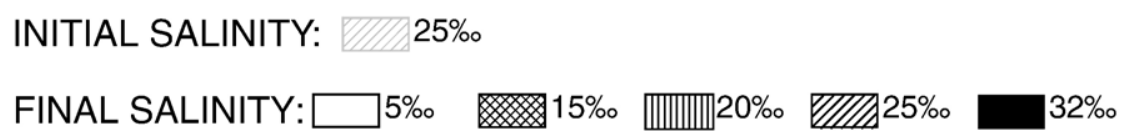

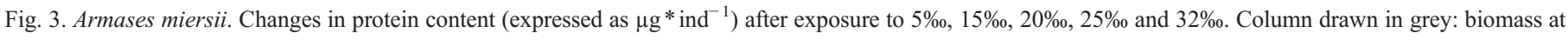

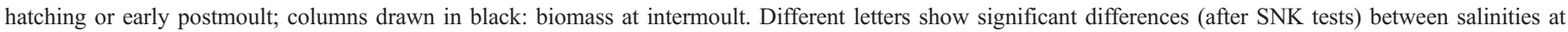
hatching and intermoult.

term cultivation, see Anger et al., 2000; Torres et al., 2006). Ovigerous females were isolated in individual aquaria and kept under otherwise identical conditions until larvae hatched.

All larval stages were mass-reared at constant salinities (25\% for $A$. miersii and $A$. roberti, 32\%o for $A$. ricordi) and otherwise identical conditions as the adults (see above). They were fed ad libitum with freshly hatched Artemia sp nauplii. Newly hatched larvae were used for experiments (for details see Fig. 1) or mass-reared to subsequent stages in 400-mL bowls without aeration. Larval density was initially 50 per bowl (Zoea I), thereafter decreased according to increasing size in the following zoeal stages $(30,20,10$, respectively). Filtered (pore size $1 \mu \mathrm{m})$ seawater (32\%o) was mixed with appropriate amounts of desalinated freshwater to obtain the experimental salinities $(5,10,15,20$ and $25 \%$ ). In daily intervals, water was changed, dead larvae were removed, new food was added, and cultures were controlled for ecdyses. Freshly moulted larvae were transferred to new bowls to ensure that all larvae used in experiments had the same moulting history and the same age within each moulting cycle.

\subsection{Experimental design}

Each set of experiments comprised treatments with a series of salinities (ranging from 5\% to 32\%o). Larval exposure lasted from early postmoult $(<12 \mathrm{~h}$ after hatching or moulting) to the intermoult stage (ca. $50 \%$ of the moulting cycle, see Table 1; Fig. 1). These treatments represent conditions of optimal salinity, severe, and moderate osmotic stress, respectively.

In each treatment, five replicate groups of larvae were reared in 400-mL bowls. Samples of larvae were taken at hatching (Zoea I) or at early postmoult (later larval stages), and again at the end of each experiment. In all samples, larval dry mass (W), and contents of total lipid and protein were measured (see below).

\subsection{Biochemical analyses}

Samples for biochemical analyses were gently rinsed in distilled water for $10 \mathrm{~s}$ and blotted on filter paper. Subsequently, they were transferred to $1.5 \mathrm{~mL}$ microcentrifuge vials and frozen at $-80{ }^{\circ} \mathrm{C}$. The samples were left in a vacuum drier (Finn-Aqua Lyovac GT2E) for $48 \mathrm{~h}$ and their dry mass was determined in a Sartorius MC1 RC 210 S balance (precision: 0,01 $\mathrm{mg}$, capacity $210 \mathrm{~g}$ ). Afterwards, they were homogenized by sonication (Branson, Sonifier, Cell Disruptor B 15) with 5 strokes of $5 \mathrm{~s}$, on ice and each homogenate was divided in two aliquots to perform lipid and protein content determinations. 

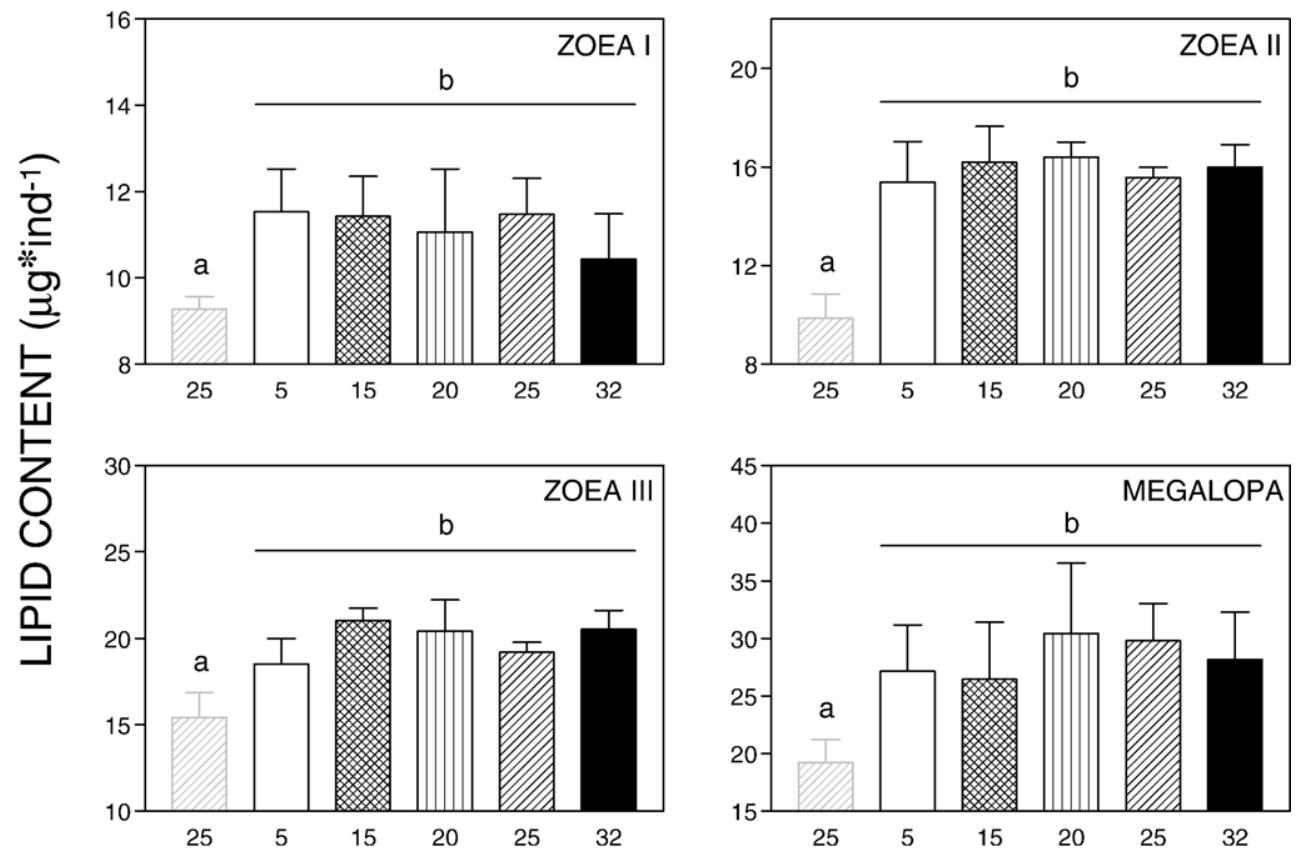

SALINITY (\%०)

INITIAL SALINITY: 25\%。

FINAL SALINITY: $\square 5 \%$ 15\%。

Fig. 4. Armases miersii. Changes in lipid content (expressed as $\mu \mathrm{g}^{*} \mathrm{ind}^{-1}$ ) after exposure to $5 \%$, $15 \%$, 20\%, 25\% and $32 \%$. Column drawn in grey: biomass at hatching or early postmoult; columns drawn in black: biomass at intermoult. Different letters show significant differences (after SNK tests) between salinities at hatching and intermoult.

\subsubsection{Protein determination}

The total protein content of the homogenate was determined using a modified method (Torres et al., 2007) after Lowry et al.

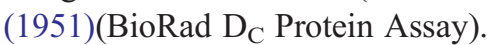

\subsubsection{Lipid determinations}

The total lipid content of the homogenate was determined after the sulphophosphovanillin method following Zöllner and Kirsch (1962), modified for microplates. $40 \mu \mathrm{L}$ of homogenate were mixed with $300 \mu \mathrm{L}$ of ice-cold $\mathrm{CHCl}_{3} / \mathrm{CH}_{3} \mathrm{OH}$ (2:1). After $15 \mathrm{~min}$ incubation at room temperature, the samples were centrifuged at $10.000 \mathrm{~g}$ for $20 \mathrm{~min}$ at $4{ }^{\circ} \mathrm{C}$.
$180 \mu \mathrm{L}$ of the lower phase were transferred to new tubes. These were left open to dry in a Thermomixer Eppendorf for $90 \mathrm{~min}$ at $56{ }^{\circ} \mathrm{C}$ with shaking at $700 \mathrm{rpm}$. The dried pellet was dissolved in $200 \mu \mathrm{L}$ of $\mathrm{H}_{2} \mathrm{SO}_{4}$ conc. and incubated for $10 \mathrm{~min}$ at $95{ }^{\circ} \mathrm{C}$ with shaking at $1400 \mathrm{rpm}$ (in a Thermomixer Eppendorf, with the tubes closed). After cooling for $20 \mathrm{~min}$ at room temperature, 8 replicates of $20 \mu \mathrm{L}$ from each sample were distributed in two 96-well microplates. In the first plate (Blank: Plate 0) $300 \mu \mathrm{L}$ of $\mathrm{H}_{3} \mathrm{PO}_{4}$ conc. were added; in the second (Plate 1), $300 \mu \mathrm{L}$ of vanillin solution $(8 \mathrm{mM}$ $\mathrm{H}_{3} \mathrm{PO}_{4}$ conc.). The microplates were incubated for colour development, $40 \mathrm{~min}$ at room temperature and subsequently

Table 3

Armases ricordi. Two-way ANOVA to evaluate the effect of salinity and larval instar on dry mass, protein and lipid content (log-transformed data)

\begin{tabular}{|c|c|c|c|c|c|c|c|c|c|}
\hline \multirow[b]{2}{*}{ Factor } & \multicolumn{3}{|c|}{ Dry mass } & \multicolumn{3}{|c|}{ Protein } & \multicolumn{3}{|c|}{ Lipids } \\
\hline & $d f$ & MS & $F$ & $d f$ & MS & $F$ & $d f$ & MS & $F$ \\
\hline $\operatorname{Instar}(I)$ & 4 & 1344 & $7171 * * *$ & 4 & 2025 & $4101^{* * *}$ & 4 & 1368 & $3242^{* * *}$ \\
\hline Salinity $(S)$ & 3 & 24.7 & $131 * * *$ & 2 & 4.1 & $8.3^{* * *}$ & 3 & 15 & $37 * * *$ \\
\hline$I \times S$ & 12 & 0.6 & $3.2 * * *$ & 12 & 1.3 & $2.7 * *$ & 12 & 1.8 & $4.0^{* *}$ \\
\hline Error & 77 & 0.2 & & 80 & 0.5 & & 77 & 0.4 & \\
\hline
\end{tabular}

Symbols: $d f$ : degrees of freedom, MS: means squares. Mean squares are $\left(1 \times 10^{-2}\right)$. Significant levels are indicated as follows: ns: not significant; $*:<0.05, * *:<0.01$, $* * *:<0.001$. 

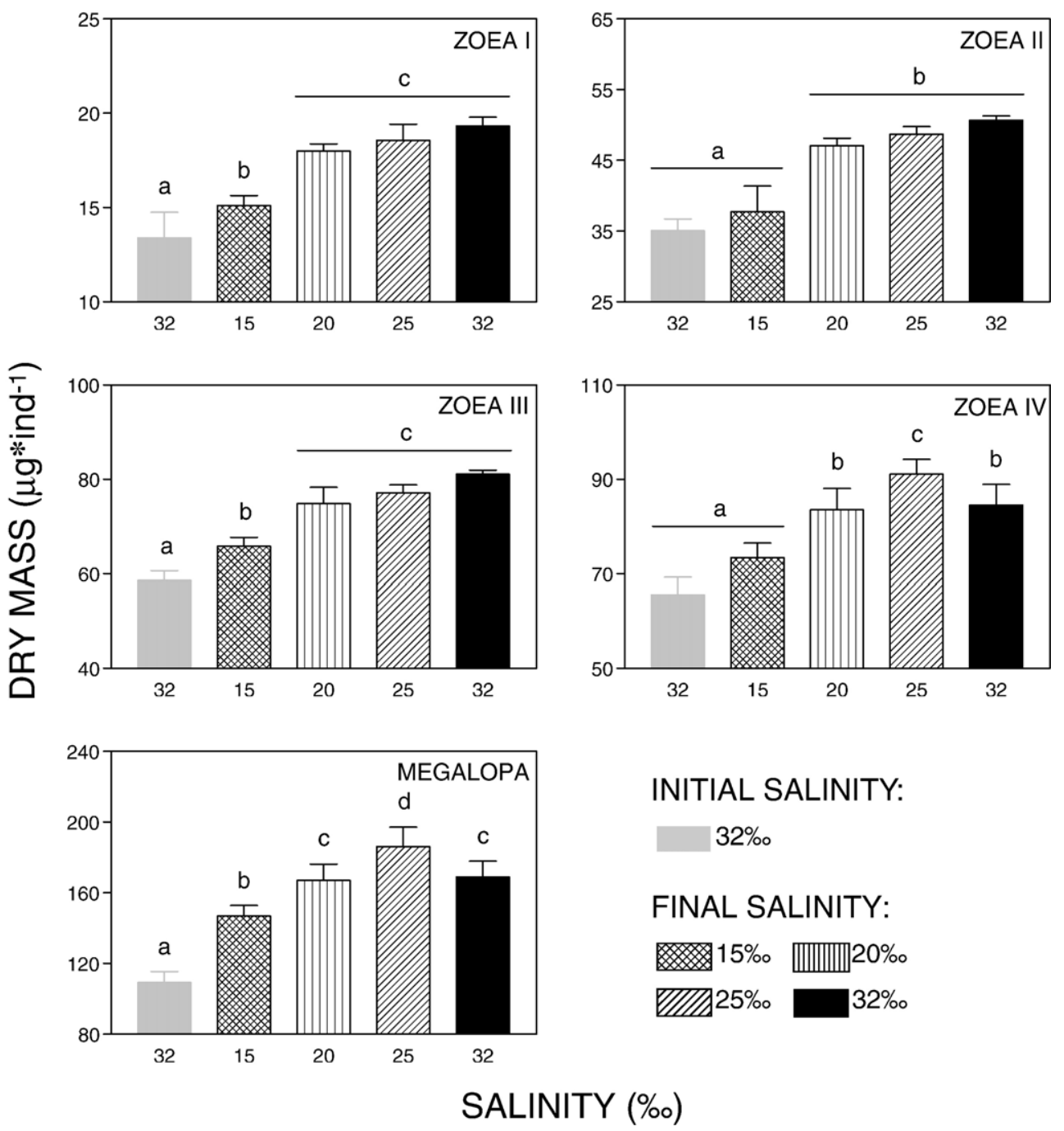

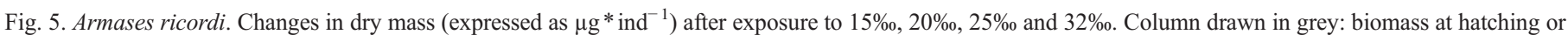

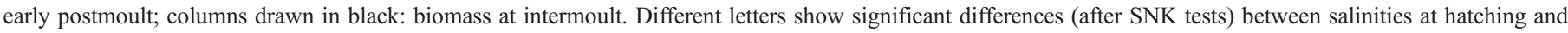
intermoult.

measured (Thermoelectron Multiskan ${ }^{\circledR}$ Spectrum spectralphotometer, wavelength: $530 \mathrm{~nm}$ ). The final values were obtained as the difference between Plate 1 and Plate 0 . The calibration curve was obtained by dilutions of a standard solution of cholesterol.

\subsection{Statistical analyses}

Statistical analyses were performed following Zar (1996). Data sets from A. miersii and A. ricordi were analysed by twoway ANOVA with developmental stage and salinity as fixed factors. Data from A. roberti were analysed for each stage separately using one-way ANOVA with salinity as factor, because different test salinities were used in different larval instars. For all stages, planned comparisons were made in order to test for significant growth from hatching or early postmoult to intermoult. The number of replicates was 4-5 for each species and stage-salinity combination.
When significant differences were detected in the ANOVAs, comparisons between different factors were performed with the Student-Newman-Keuls test (SNK). The critical level $(\alpha)$ to reject the null hypothesis was fixed at 0.05 . Before performing ANOVAs, normality (normal plots) and variance homogeneity (Cochran test) were checked. When raw data failed to meet the assumptions logarithmically transformed data showed normal errors and variance homogeneity.

\section{Results}

\subsection{A. miersii}

During the period from postmoult to intermoult, significant increments in larval dry mass (i.e. $W$ growth) were found in all larval stages and at all salinities. However, salinity affected the rate of developmental increase in $W$, and these salinity effects varied significantly among instars (Table 2 ). In the Zoea I, the 
intermoult level of $\mathrm{W}$ was significantly higher at 5\%o than at $15 \%$ - $32 \%$ o (Fig. 2). The following larval stages, by contrast, grew at $5 \%$ less than in treatments with higher salinities, while maximum $\mathrm{W}$ growth was achieved at $32 \%$.

The levels of both the protein and the lipid fraction increased during development from postmoult to intermoult in all larval stages and in all salinity treatments (Figs. 3, 4). The protein contents measured at intermoult were in the first and second zoeal instar not significantly affected by salinity. The Zoea III, by contrast, showed maximum protein growth at $15 \%$, i.e. significantly lower increments in treatments with either higher or lower salinities. In the Megalopa, maximal protein growth was observed at 5\% (Fig. 3).

The lipid content reached at intermoult was generally not affected by salinity (Table 2, Fig. 4).

\subsection{A. ricordi}

Effects of salinity on intermoult levels of $\mathrm{W}$, protein and lipid varied among larval instars (Table 3). In all stages, intermoult $\mathrm{W}$ was lowest at the lowest test salinity (15\%; Fig. 5). W growth in the early stages (Zoea I -III) did not vary in the range $20-32 \%$, but later instars showed a maximum at $25 \%$ (Fig. 5). The Zoea II and IV did not show significant developmental increments in $\mathrm{W}$ at $15 \%$, while significant $\mathrm{W}$ growth occurred in all treatments with higher salinities (Fig. 5).

The increments in protein occurring during development from postmoult to intermoult were in all stages and treatments significant (Fig. 6). However, the protein level at the intermoult stage showed in the Zoea I and Zoea II a significantly increasing trend with increasing salinity, while the Zoea III showed a peak at $20 \%$, and no salinity effect was found in the Zoea IV (Fig. 6). In contrast to the zoeal stages, the megalopae showed a higher protein gain in the 15,20 , and $25 \%$ o treatments compared to the control condition $(32 \%)$ ).

In the lipid fraction, the rate of growth (increment from postmoult to intermoult) increased significantly in treatments with increasing salinity, except for the Megalopa stage (Fig. 7). In the range $20-32 \%$, significant salinity effects were found

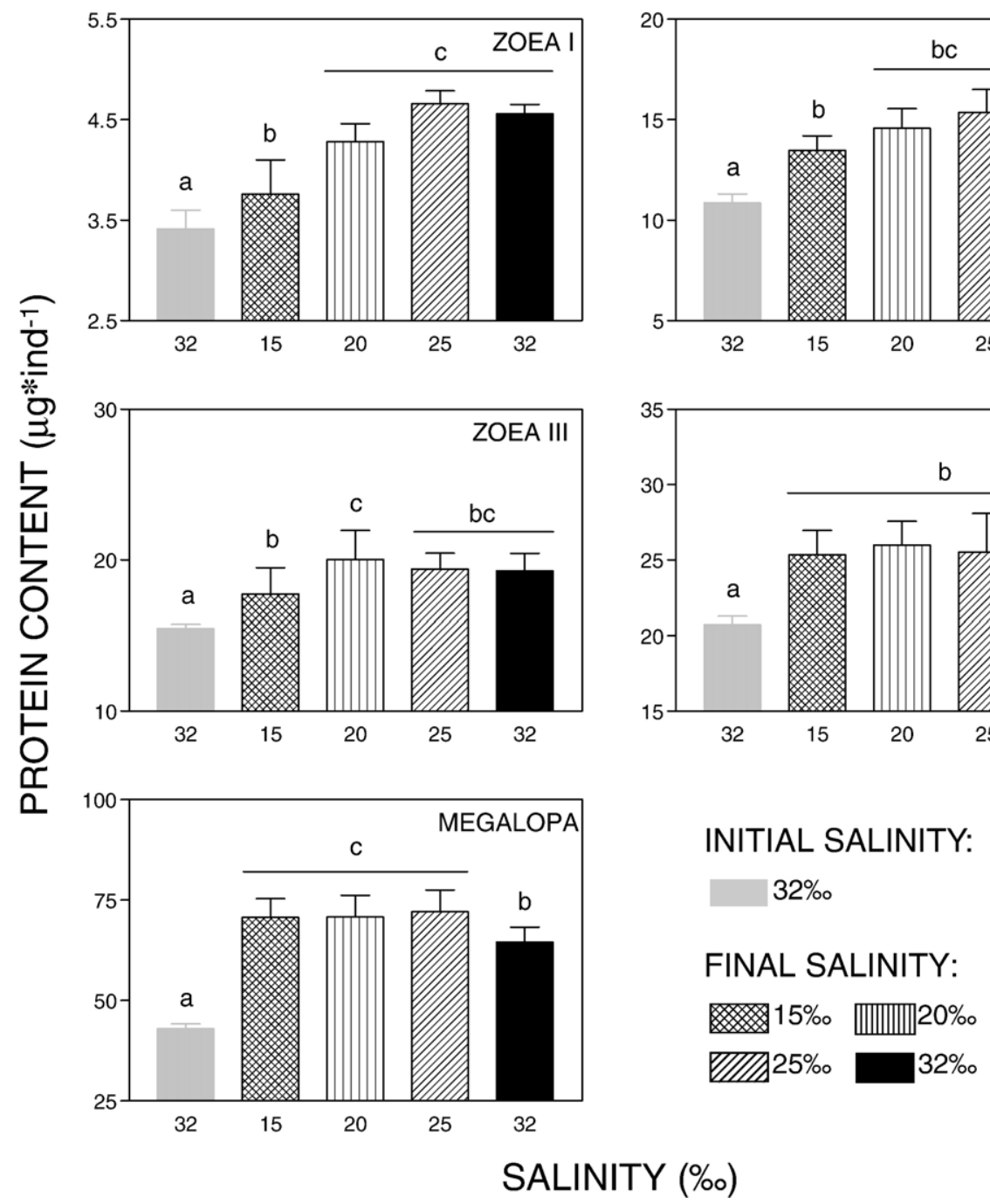

Fig. 6. Armases ricordi. Changes in protein content (expressed as $\mu \mathrm{g}^{*}$ ind $^{-1}$ ) after exposure to $15 \%, 20 \%$, $25 \%$ and $32 \%$. Column drawn in grey: biomass at hatching or early postmoult; columns drawn in black: biomass at intermoult. Different letters show significant differences (after SNK tests) between salinities at hatching and intermoult. 

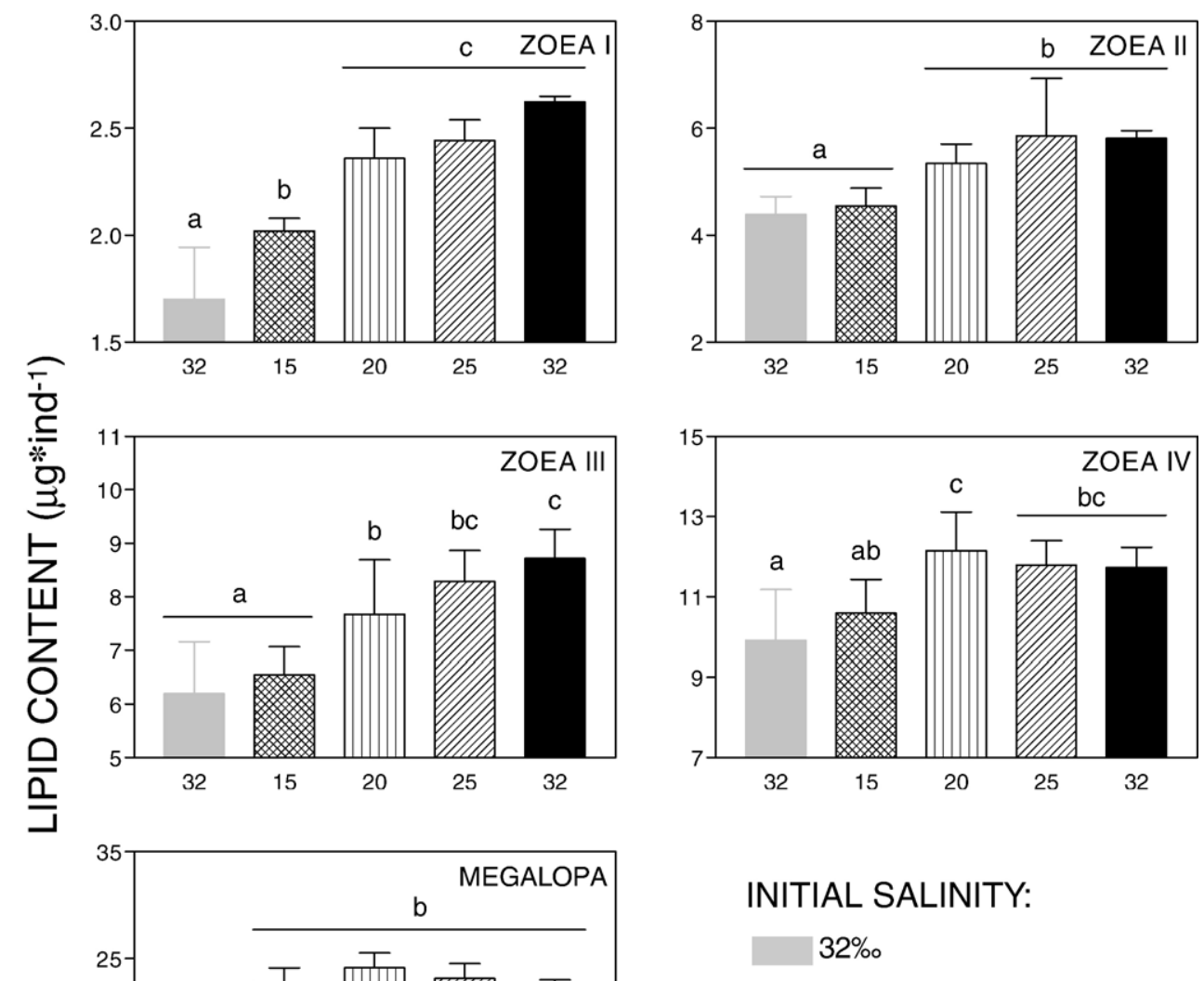

FINAL SALINITY:
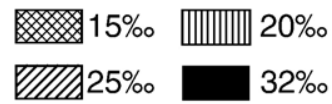

SALINITY (\%०)

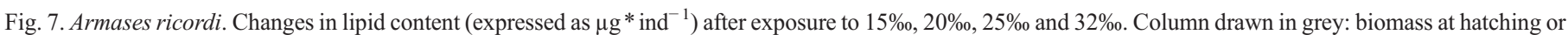

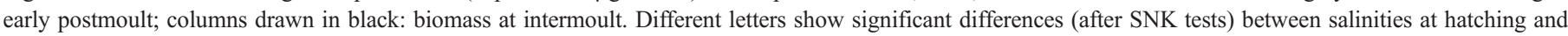
intermoult.

only in the Zoea III, where the lipid content at intermoult was higher at $32 \%$ than at $20 \%$. No lipid growth was found in the zoeal stages II, III and IV exposed to 15\%; at higher salinities, lipid growth was always significant.

\subsection{A. roberti}

In this species, all larval stages revealed a significant $\mathrm{W}$ growth from postmoult to intermoult (Fig. 8). Salinity affected the rate of growth in larval $\mathrm{W}$ only in the early instars (Zoea IIII, Table 4). W measured at intermoult was lower at 10-15\% than at higher salinities. In the zoeal stages I and II it was maximum at 25-32\%o, in the Zoea III at 25\% (Fig. 8). Intermoult $\mathrm{W}$ in the Zoea IV and Megalopa tended to be higher in treatments with $10 \%$ o- $25 \%$ compared to higher salinities, but the differences were statistically not significant.

Protein growth was significant in all stages and at all salinities. The effect of salinity was statistically significant only in the Zoea IV and Megalopa (Table 4). In the Zoea IV, the lowest developmental protein increment was found at $15 \%$, while the Megalopa showed a minimum at $10 \%$ and maximal increments in the range $15 \%$ - $25 \%$ (Fig. 9).

In the Zoea I stage, only the control condition (32\%o) allowed for a significant lipid growth during development from postmoult to intermoult. All other larval instars showed at all salinities significant increments in their lipid contents. Lipid growth was in the Zoea I, III and Megalopa affected by salinity (statistically not significant in the Zoea II; Table 4). While the zoeal stages I and III showed at intermoult maximal lipid contents at a condition of $32 \%$, the Megalopa reached maximum lipid growth at 25\% (Fig. 10).

\subsection{Interspecific comparisons}

While detailed statistical analyses show significant salinity effects on growth rates and intermoult levels of total $W$, protein and lipid contents in individual species and larval stages (see sections above), an index of relative (biomass-specific) changes 

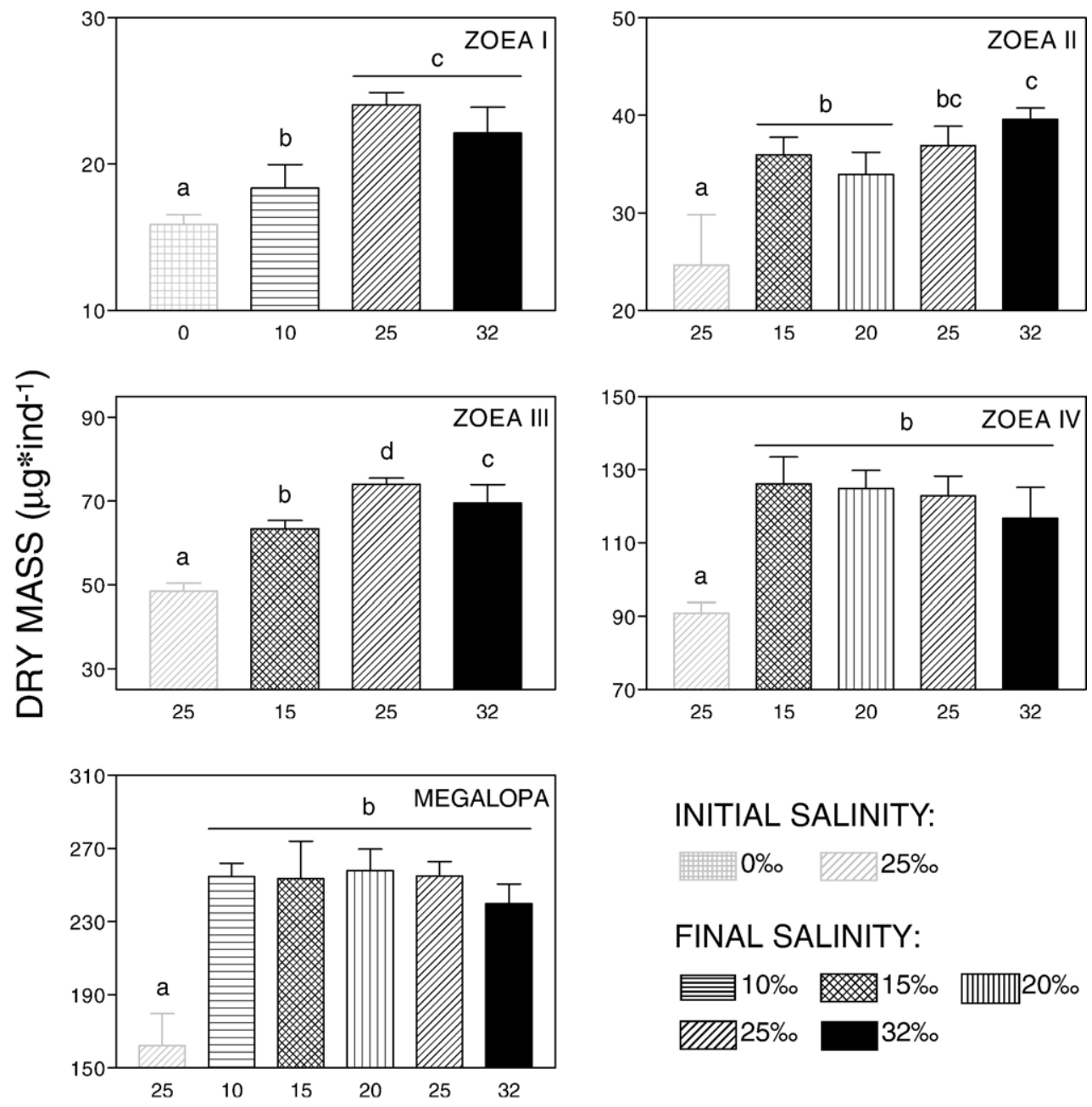

FINAL SALINITY:

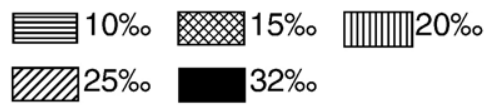

\section{SALINITY (\%)}

Fig. 8. Armases roberti. Changes in dry mass (expressed as $\mu \mathrm{g} *$ ind $^{-1}$ ) after exposure to $10-32 \%$. Column drawn in grey: biomass at hatching or early postmoult; columns drawn in black: biomass at intermoult. Different letters show significant differences (after SNK tests) between salinities at hatching and intermoult.

in developmental growth rates $\left(B_{\mathrm{H}-\mathrm{L}}^{\prime}\right)$ removes the confounding effects of interspecfic differences in stage-specific biomass, allowing for a comparative quantification and visualization of salinity effects:

$B_{\mathrm{H}-\mathrm{L}}^{\prime}=\left(B_{\mathrm{H}}-B_{\mathrm{L}}\right) \cdot 100 /\left(B_{25} \cdot\left(S_{\mathrm{H}}-S_{\mathrm{L}}\right)\right)$

where $B_{\mathrm{H}}$ is individual biomass ( $W$, protein or lipid content per larva) measured at the end of the experiment (at intermoult) at the higher salinity $\left(S_{\mathrm{H}}\right)$ in an interval of salinities $\left(S_{\mathrm{H}}-S_{\mathrm{L}}\right)$, and $B_{\mathrm{L}}$ is the biomass at the lower salinity $\left(S_{\mathrm{L}}\right)$. The dimension is a percentage of variation in biomass $(\% B$ per $\%$ salinity change) in relation to the biomass at the reference condition, 25\%o $\left(B_{25}\right)$.

Biomass-specific effects of salinity on the intermoult levels of larval biomass are shown in Fig. 11, comparing in each stage and species two salinity ranges, $15-25 \%$ and $25-32 \%$ $\left(B_{25-15}^{\prime}\right.$ and $\left.B_{32-25}^{\prime}\right)$. Positive $B^{\prime}$ values indicate a higher biomass increment at the higher as compared to the lower salinity ( $B_{\mathrm{H}}$ vs. $B_{\mathrm{L}}$ ), while negative values indicate that the biomass increment (from postmoult to intermoult) was lower at the higher salinity.

$A$. miersii showed generally very small values of $B_{25-15}^{\prime}$ and $B_{32-25}^{\prime}(-1.3$ to $+1.1 \%$ per salinity unit), indicating only a weak response of larval biomass to variations in salinity (Fig. 11). For $W$, a developmental change from negative to positive $B_{32-25}^{\prime}$ values indicated an ontogenetic shift in the optimal salinity, where increments in biomass were maximal $(25 \%$ o in earlier larval stages, $32 \%$ in later stages).

$A$. ricordi showed a stronger susceptibility to salinity variations than the other two species. The $B_{25-15}^{\prime}$ values were $>2 \%$ per salinity unit, except for protein growth in the Zoea IV and both protein and lipid growth in the Megalopa (Fig. 11). Thus, salinity-induced changes in the protein and lipid contents at intermoult tended, in this species, to decrease with development. The $B_{32-25}^{\prime}$ values for protein and lipid growth 
Table 4

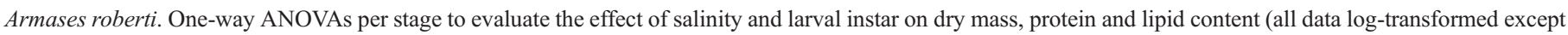
Lipids in Megalopa)

\begin{tabular}{|c|c|c|c|c|c|c|c|c|c|}
\hline \multirow[b]{2}{*}{ Factor } & \multicolumn{3}{|c|}{ Dry mass } & \multicolumn{3}{|c|}{ Protein } & \multicolumn{3}{|c|}{ Lipids } \\
\hline & $d f$ & MS & $F$ & $d f$ & MS & $F$ & $d f$ & MS & $F$ \\
\hline \multicolumn{10}{|l|}{ Zoea I } \\
\hline Salinity & 2 & 9.72 & $19.8^{* * *}$ & 2 & 0.29 & $0.66^{\mathrm{ns}}$ & 2 & 10.3 & $5.85^{*}$ \\
\hline Error & 12 & 0.49 & & 12 & 0.45 & & 12 & 1.8 & \\
\hline \multicolumn{10}{|l|}{ Zoea II } \\
\hline Salinity & 3 & 2.06 & $7.6^{* *}$ & 3 & 0.04 & $0.13^{\mathrm{ns}}$ & 3 & 1.4 & $0.36^{\mathrm{ns}}$ \\
\hline Error & 15 & 0.27 & & 15 & 0.32 & & 15 & 3.9 & \\
\hline \multicolumn{10}{|l|}{ Zoea III } \\
\hline Salinity & 2 & 3.05 & $16.4 * * *$ & 2 & 0.50 & $1.04^{\mathrm{ns}}$ & 2 & 4.4 & $6.1^{*}$ \\
\hline Error & 12 & 0.19 & & 12 & 0.48 & & 11 & 0.7 & \\
\hline \multicolumn{10}{|l|}{ Zoea IV } \\
\hline Salinity & 3 & 0.62 & $2.0^{\mathrm{ns}}$ & 3 & 2.29 & $9.80 * *$ & 3 & 3.4 & $1.11^{\mathrm{ns}}$ \\
\hline Error & 16 & 0.31 & & 16 & 0.23 & & 15 & 3.1 & \\
\hline \multicolumn{10}{|l|}{ Megalopa } \\
\hline Salinity & 4 & 0.40 & $1.7^{\mathrm{ns}}$ & 4 & 1.20 & $4.60 * *$ & 4 & 102.2 & $3.70^{*}$ \\
\hline Error & 20 & 0.24 & & 20 & 0.26 & & 19 & 27.6 & \\
\hline
\end{tabular}

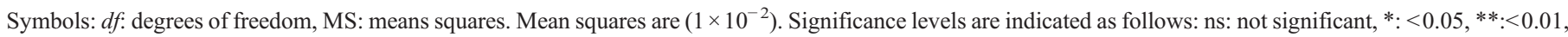
$* * *:<0.001$.

indicated an ontogenetic shift in the salinity allowing for maximum growth, from $32 \%$ in the early stages (Zoea I-IV) to $25 \%$ in later stages (Megalopa).

The larvae of $A$. roberti showed generally little sensitivity of growth to salinity variations, albeit a stronger response than in A. miersii (Fig. 11). The strongest effect was found in the lipid content, where the $B_{25-15}^{\prime}$ values of the Zoea IV and the Megalopa as well as the $B_{32-25}^{\prime}$ values of the Zoea I and Zoea III were ca. $2 \%$ per salinity unit. As in A. ricordi, maximum W, protein and lipid growth shifted from $32 \%$ (Zoea I-III) to $25 \%$ (Zoea IV-Megalopa), indicated by changes in the sign of $B_{32-25}^{\prime}$.

\section{Discussion}

Our experiments have shown that, within the genus $\mathrm{Ar}$ mases, effects of salinity on larval biomass vary among species and ontogenetic stages. These differences appear to be related to differential osmoregulatory capacities and ecological characteristics in each species and larval stage.

The larval development of $A$. miersii occurs in isolated supratidal rock pools, which are characterized by strong variations in salinity due to evaporation and rainfalls (Anger, 1995; Schuh and Diesel, 1995). The larvae of this species hatch with strong hyper-osmoregulatory capacities within the range $5-25 \%$ (Charmantier et al., 1998). This capability is most probably based on an increase in the level of mRNA encoding for the $\mathrm{Na}^{+}-\mathrm{K}^{+}$-ATPase, one of the key enzymes in osmoregulatory mechanisms (Torres et al., in prep.). These physiological traits can be considered as adaptive, because they enhance the larval tolerance of naturally occurring salinity variations, reducing osmotic stress and physiological damage. This should explain why A. miersii showed, in the present study, the smallest salinity-induced changes in biomass growth, especially in the fractions of protein and lipid. The increase in total $W$ growth at higher salinities may reflect an uptake of inorganic substances (Anger, 2003). No effects were detected in the intermoult lipid content, and protein growth showed in the Zoea III a peak at 15\% rather than in full-strength seawater. These observations indicate that reduced salinities did not negatively affect, or sometimes even favoured larval growth in this species.

Larval $A$. ricordi and $A$. roberti exposed to salinity variations showed compared to $A$. miersii, wider variations in biomass. The larvae of $A$. ricordi, which develop in coastal marine waters (Díaz and Ewald, 1968; Alvarez and Ewald, 1990, Diesel and Schuh, 1998), experience in nature normally lesser variations in salinity than A. miersii. This corresponds with a weaker osmoregulatory capacity (Charmantier et al., unpublished data) and greater salinity-induced changes in biomass; especially in the Zoea I (present study). In the natural environment, a direct release of the larvae into coastal waters prevents osmotic stress and reduced growth. In later larval instars, the condition allowing for maximum biomass growth shifted from $32 \%$ to $25 \%$. This ontogenetic change in the salinity optimum may be related to the peculiar osmoregulatory patterns in the Megalopa, which reveals a strong hyperosmoregulatory capacity, accompanied by a shift of the isoosmotic point from $32 \%$ to $25 \%$ (Charmantier et al., unpublished data).

The physical conditions experienced by the larval instars of $A$. roberti vary greatly during ontogeny in the natural environment. The Zoea I faces freshwater after hatching in riverine habitats, while the following zoeal stages develop in estuarine or coastal marine waters, and finally, the Megalopa encounters during its upstream re-immigration brackish or freshwater conditions (Torres et al., 2006; Anger et al., 2006). These changes in the surrounding media experienced by 


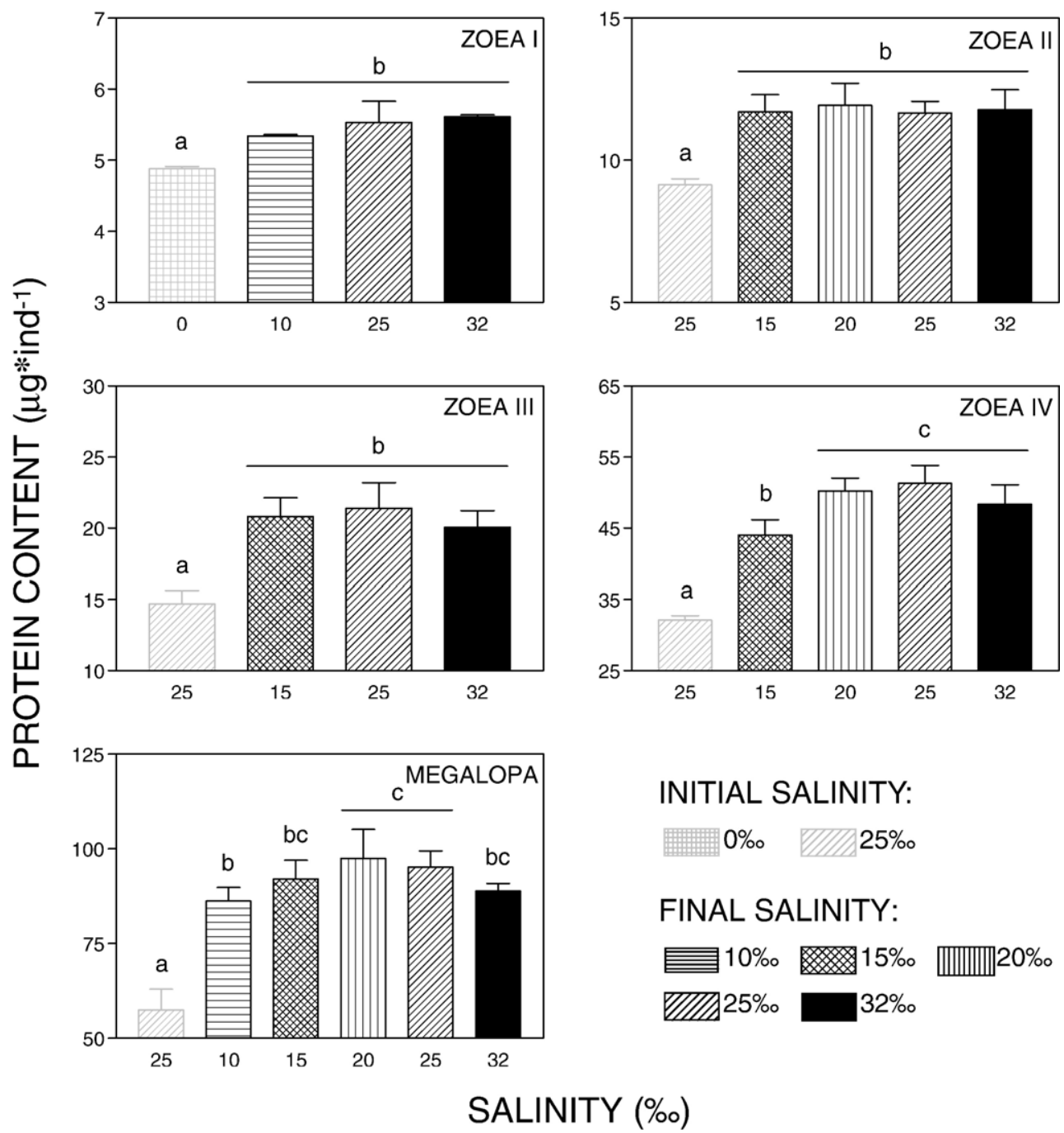

Fig. 9. Armases roberti. Changes in protein content (expressed as $\mu \mathrm{g}^{*}$ ind $^{-1}$ ) after exposure to $10-32 \%$. Column drawn in grey: biomass at hatching or early postmoult; columns drawn in black: biomass at intermoult. Different letters show significant differences (after SNK tests) between salinities at hatching and intermoult.

successive larval stages in the field correspond with changes in the ontogenetic pattern of osmoregulation under constant laboratory conditions (Charmantier et al., unpublished data). In agreement with these patterns, the variations of biomass in the Zoea I exposed to salinities between $10 \%$ and $32 \%$ were low, while the following zoeal stages showed a stronger response within a narrower salinity range $(15 \%-32 \%)$.

The euryhaline larval stages of the three species of Armases studied here showed smaller salinity-induced changes in biomass than the Zoea I of the stenohaline species Cancer pagurus and Homarus gammarus (Fig. 11; cf. Torres et al., 2002). Hence, a low sensitivity of growth to salinity variations appears to be related to euryhalinity. Unfavourably low salinity may cause a reduction of the average rate of feeding or of growth efficiency, presumably due to metabolic disadjustments induced by osmotic stress, and such effects should be stronger in osmoconformers or weak osmoregulators as compared to strong osmoregulators. For instance, significant reduction in the metabolism of the Zoea I stage of C. maenas exposed to low salinities was observed to cause reduced net growth efficiency (Anger et al., 1998).

The juvenile stages of the portunid crabs Callinectes sapidus, C. similis and Scylla serrata tolerate a wide range of salinities and their growth is weakly affected by salinity variations in the range 10-40\% (Guerin and Stickle, 1997; Ruscoe et al. 2004). In contrast, juveniles of another portunid, Portunus pelagicus, tolerate a narrower range of salinities, exhibiting also a reduced growth at low salinities (Romano and Zeng 2006). As in the present study, these interspecific differences in the responsiveness of survival and growth to changes in salinity correspond with differences in the species-specific osmoregulatory capabilities (Romano and Zeng 2006). This suggests that effects of salinity variations on juvenile growth are physiologically similar to effects observed in larval stages: strong osmoregulatory capabilities buffer detrimental effects of variable salinity. In summary, our results corroborate our previous prediction that 


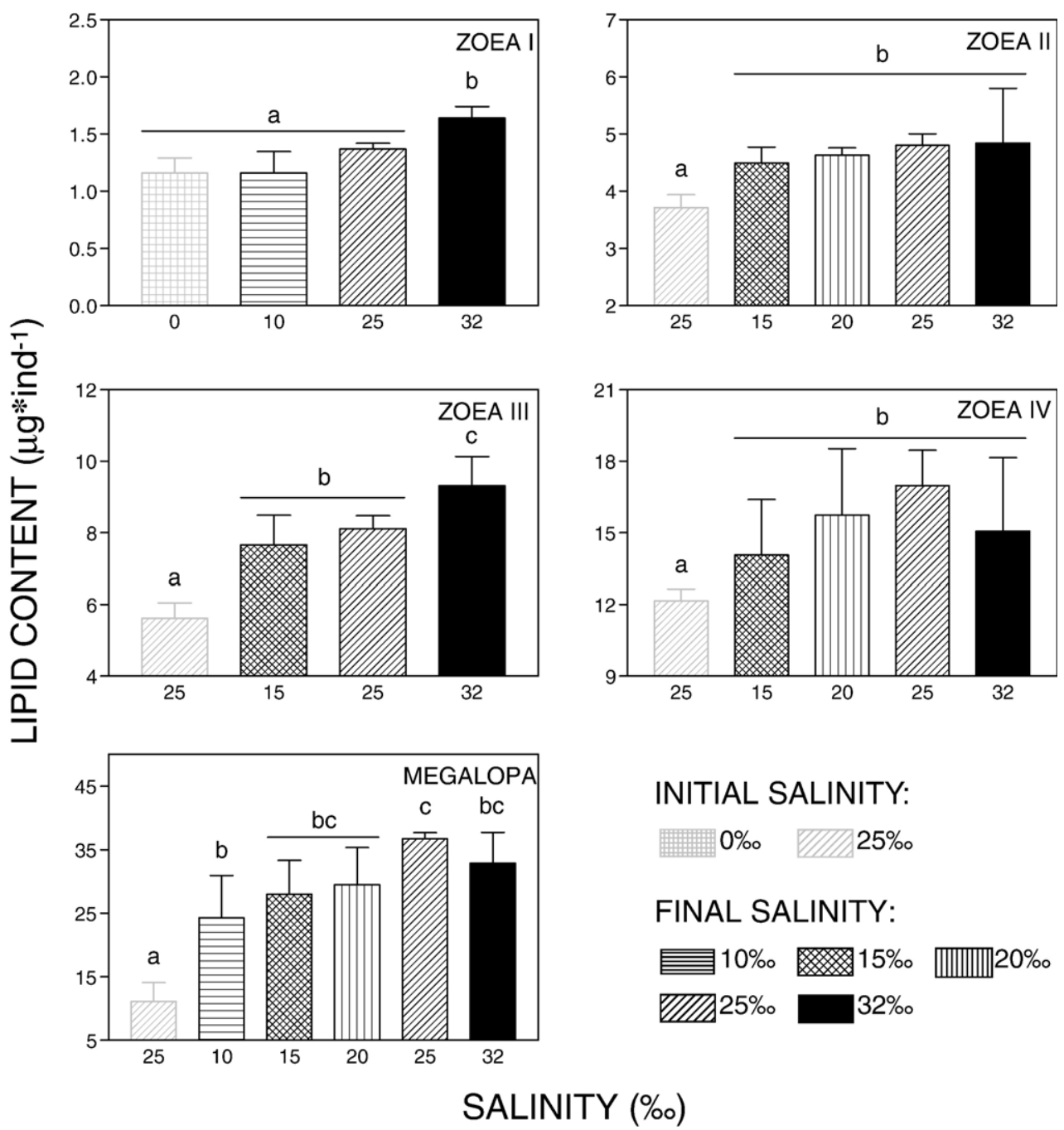

Fig. 10. Armases roberti. Changes in lipid content (expressed as $\mu \mathrm{g}^{*}$ ind $^{-1}$ ) after exposure to $10-32 \%$. Column drawn in grey: biomass at hatching or early postmoult; columns drawn in black: biomass at intermoult. Different letters show significant differences (after SNK tests) between salinities at hatching and intermoult.

ontogenetic changes in the capability of osmoregulation are reflected not only in differential larval survival, but also in responses of growth to reduced salinities.

\section{Acknowledgements}

We thank U. Nettelmann for help in the rearing of larvae and crabs. G.T. was financially supported by the Deutscher Akademischer Austauschdienst (DAAD, Bonn, Germany) funding this study as a part of her doctoral dissertation, and L.G. by the Alexander-von-Humboldt Foundation (Bonn, Germany) with a postdoctoral research grant. The experiments comply with the current animal and manipulation laws in Germany.

\section{References}

Abele, L.G., 1992. A review of the grapsid crab genus Sesarma (Crustacea: Decapoda: Grapsidae) in America, with description of a new genus. Smithsonian Contrib. Zool. 527, 1-60.
Alvarez, Z., Ewald, J., 1990. Efectos de la salinidad y la dieta sobre el desarrollo larvario de Sesarma ricordi (Milne Edwards, 1893) (Decapoda: Grapsidae). Sci. Mar. 54, 55-60.

Anger, K., 1995. Developmental biology of Armases miersii (Grapsidae), a crab breeding in supratidal rock pools. 1. Facultative lecithotrophy of larval stages. Mar. Ecol. Prog. Ser. 117, 71-81.

Anger, K., 2001. The Biology of Decapod Crustacean Larvae. Crustacean Issues, vol. 14. Balkema, Lisse.

Anger, K., 2003. Salinity as a key parameter in the larval biology of decapod crustaceans. Inv. Rep. Dev. 43, 29-45.

Anger, K., Riesebeck, K., Püschel, C., 2000. Effects of salinity on larval and early juvenile growth of an extremely euryhaline crab species, Armases miersii (Decapoda: Grapsidae). Hydrobiologia 426, 161-168.

Anger, K., Spivak, E., Bas, C., Ismael, D., Luppi, T., 1994. Hatching rhythms and dispersion of decapod crustacean larvae in a brackish coastal lagoon in Argentina. Helgol. Meeresunters. 48, 445-466.

Anger, K., Spivak, E., Luppi, T., 1998. Effects of reduced salinities on development and bioenergetics of early larval shore crab, Carcinus maenas. J. Exp. Mar. Biol. Ecol. 220, 287-304.

Anger, K., Torres, G., Giménez, L., 2006. Metamorphosis of a sesarmid river crab, Armases roberti: stimulation by adult odours vs inhibition by salinity stress. Mar. Freshw. Behav. Physiol. 39, 269-278. 
Chace Jr., F.A., Hobbs, H.H., 1969. The freshwater and terrestrial decapod crustaceans of the West Indies with special reference to Dominica. Bull USA Nat. Mus. 292, 1-258.

Charmantier, G., Charmantier-Daurès, M., Anger, K., 1998. Ontogeny of osmoregulation in the grapsid crab Armases miersii (Crustacea, Decapoda). Mar. Ecol. Prog. Ser. 164, 285-292.

Charmantier, G., Giménez, L., Charmantier-Daures, M., Anger, K., 2002. Ontogeny of osmoregulation, physiological plasticity, and export strategy in the grapsid crab Chasmagnathus granulata (Crustacea, Decapoda). Mar. Ecol. Prog. Ser. 229, 185-194.

Cieluch, U., Anger, K., Charmantier-Daures, M., Charmantier, G., 2007. Salinity tolerance, osmoregulation, and immunolocalization of $\mathrm{Na}^{+}-\mathrm{K}^{+}-$ATPase in larval and early juvenile stages of the Chinese mitten crab, Eriocheir sinensis (Decapoda, Grapsoidea). Mar. Ecol. Progr. Ser. 329, 169-178.

Cuesta, J.A., Schuh, M., Diesel, R., Schubart, C.D., 1999. Abbreviated development of Armases miersii (Grapsidae: Sesarminae), a crab that breeds in supralittoral rock pools. J. Crust. Biol. 19, 26-41.

Díaz, H., Ewald, J.J., 1968. A comparison of the larval development of Metasesarma rubripes (Rathbun) and Sesarma ricordi H Milne Edwards (Brachyura, Grapsidae) reared under laboratory conditions. Crustaceana 2, 225-248.

Diesel, R., Schuh, M., 1998. Effect of salinity and starvation on larval development of the crabs Armases ricordi and A. roberti (Decapoda: Grapsidae) from Jamaica, with notes on the biology and ecology of adults. J. Crust. Biol. 18, 423-436.

Greenaway, P., 1999. Physiological Diversity And The Colonization Of Land. In: Schram, F.R., von Vaupel Klein, J.C. (Eds.), Crustaceans and the Biodiversity Crisis, vol. 1. Leiden, Brill, pp. 823-842.

Guerao, G., Anger, K., Schubart, C.D., in press. Larvae and first-stage juveniles of the American genus Armases Abele, 1992 (Brachyura: Sesarmidae): a morphological description of two complete developments and one first zoeal stage. J. Nat. Hist.

Guerin, J., Stickle, W., 1997. A comparative study of two sympatric species within the genus Callinectes: osmoregulation, long-term acclimation to salinity and the effects of salinity on growth and moulting. J. Exp. Mar. Biol. Ecol. 218, 165-186.

Hartnoll, R.G., 1965. Notes on the marine grapsids of Jamaica. Proc. Linnean Soc. London 175, 113-147.

Herborg, L.M., Rushton, S.P., Clare, A.S., Bentley, M.G., 2003. Spread of the Chinese mitten crab (Eriocheir sinensis H. Milne Edwards) in Continental Europe: analysis of a historical data set. Hydrobiologia 503, 21-28.
Kinne, O., 1971. Salinity. In: Kinne, O. (Ed.), Marine Ecology. A comprehensive, integrated treatise on life in oceans and coastal waters, vol. 1. Wiley, London, pp. 683-1244.

Lowry, D., Rosenberg, N., Farr, A., Randall, R., 1951. Protein measurement with the Folin phenol reagent. J. Biol. Chem. 193, 265-275.

Péqueux, A., 1995. Osmotic regulation in crustaceans. J. Crust. Biol. 15, 1-60.

Romano, N., Zeng, C., 2006. The effects of salinity on the survival, growth and haemolymph osmolality of early juvenile blue swimmer crabs, Portunus pelagicus. Aquaculture 260, 151-162.

Ruscoe, I., Shelley, C., Williams, G., 2004. The combined effects of temperature and salinity on growth and survival of juvenile mud crabs (Scylla serrata Forskale). Aquaculture 238, 239-247.

Schubart, C.D., Diesel, R., 1998. Osmoregulatory capacities and penetration into terrestrial habitats: a comparative study of Jamaican crabs of the genus Armases Abele, 1992 (Brachyura: Grapsidae: Sesarminae). Bull. Mar. Sci. 62 (3), 743-752.

Schuh, M., Diesel, R., 1995. Breeding in a rock pool: larvae of the semiterrestrial crab Armases (=Sesarma) miersii (Decapoda: Grapsidae) develop in a highly variable environment. J. Exp. Mar. Biol. Ecol. 185, 109-129.

Strathmann, R.R., 1982. Selection for retention or export of larvae in estuaries. In: Kennedy, V.S. (Ed.), Estuarine Comparisons. Academic Press, San Diego, pp. 521-535.

Torres, G., Giménez, L., Anger, K., 2002. Effects of reduced salinity on the biochemical composition (lipid, protein) of zoea I decapod crustacean larvae. J. Exp. Mar. Biol. Ecol. 277, 43-60.

Torres, G., Anger, K., Giménez, L., 2006. Effects of reduced salinities on metamorphosis of a freshwater-tolerant sesarmid crab, Armases roberti: is upstream migration in the megalopa stage constrained by increasing osmotic stress? J. Exp. Mar. Biol. Ecol. 338, 134-139.

Torres, G., Charmantier-Daures, M., Chifflet, S., Anger, K., 2007. Effects of long-term exposure to different salinities on the location and activity of $\mathrm{Na}^{+}-\mathrm{K}^{+}$-ATPase in the gills of juvenile mitten crab, Eriocheir sinensis. Comp. Biochem. Physiol. A 147, 460-465.

Zar, J., 1996. Biostatistical Analysis, 3rd ed. Prentice-Hall, London.

Zöllner, N., Kirsch, K., 1962. Über die quantitative Bestimmung von Lipoiden (Mikromethode) mittels der vielen natürlichen Lipoiden (allen bekannten Plasmalipoide) gemeinsamen Sulphophosphovanillin-Reaktion. Z. Gesamte Exp. Med. 135, 545-561. 


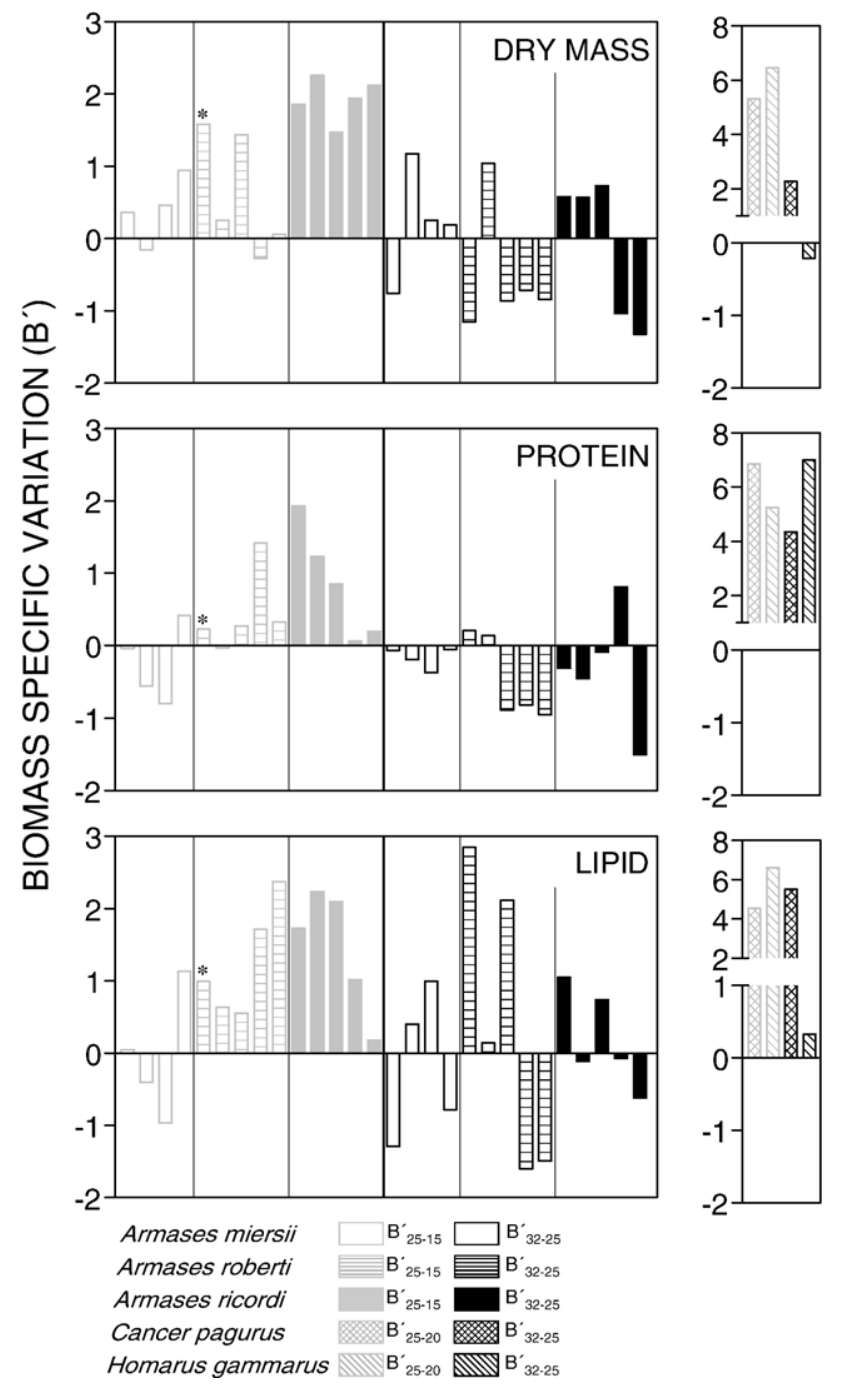

Fig. 11. Biomass-specific variation for each stage and species studied, exposed to different salinities. Variation at the interval $15 \%{ }_{0}-25 \%$ or $20 \%{ }_{0}-25 \%$ : Columns drawn in grey; at the interval 25\%o-32\%: columns drawn in black. Armases miersii (ZI-M): blank columns; A. roberti (ZI-M): horizontally striped columns; A. ricordi (ZI-M): full columns; Cancer pagurus (ZI): crossed columns; Homarus gammarus (ZI): diagonally striped columns. * For Zoea I of $A$. roberti, we calculated $B^{\prime}{ }_{25-10}$ (i.e. using 10\%), since 15\%o was not measured. Data from C. pagurus and H. gammarus, after Torres et al. (2002). 